\title{
Accumulation of specific flavonoids in soybean (Glycine max (L.) Merr.) as a function of the early tripartite symbiosis with arbuscular mycorrhizal fungi and Bradyrhizobium japonicum (Kirchner) Jordan
}

\author{
Pedro M. Antunes ${ }^{\mathrm{a}, *}$, Amarilis de Varennes ${ }^{\mathrm{b}}$, Istvan Rajcan ${ }^{\mathrm{c}}$, Michael J. Goss ${ }^{\mathrm{a}}$ \\ ${ }^{a}$ Department of Land Resource Science, University of Guelph, Guelph, Ont., Canada NIG2W1 \\ ${ }^{\mathrm{b}}$ Departamento de Química Agrícola e Ambiental, Instituto Superior de Agraonomia, Tapada da Ajuda, 1349-017 Lisboa, Portugal \\ ${ }^{\mathrm{c}}$ Department of Plant Agriculture, Crop Science Building, University of Guelph, Guelph, Ont., Canada N1G2W1
}

Received 20 February 2005; received in revised form 19 September 2005; accepted 28 September 2005

Available online 2 November 2005

\begin{abstract}
This study is the first report assessing the effect of soil inoculation on the signalling interaction of Bradyrhizobium japonicum, arbuscular mycorrhizal fungi (AMF) and soybean plants throughout the early stages of colonisation that lead to the tripartite symbiosis. In a study using soil disturbance to produce contrasting indigenous AMF treatments, the flavonoids daidzein, genistein and coumestrol were identified as possible signals for regulating the establishment of the tripartite symbiosis. However, it was unclear whether soil disturbance induced changes in flavonoid root accumulation other than through changing the potential for AMF colonization. In this study, soil treatments comprising all possible combinations of AMF and B. japonicum were established to test whether (1) modifications in root flavonoid accumulation depend on the potential for AMF colonization, and (2) synthesis and accumulation of flavonoids in the roots change over time as a function of the early plant-microbial interactions that lead to the tripartite symbiosis. The study was comprised of two phases. First, maize was grown over 3-week periods to promote the development of the AM fungus Glomus clarum. Second, the interaction between soybean, G. clarum and B. japonicum was evaluated at 6, 10, 14 and 40 days after plant emergence. Root colonization by G. clarum had a positive effect on nodulation 14 days after emergence, producing, $30 \%$ more nodules which were $40 \%$ heavier than those on roots solely inoculated with B. japonicum. The tripartite symbiosis resulted in $23 \%$ more $\mathrm{N}_{2}$ being fixed than did the simpler symbiosis between soybean and B. japonicum. The presence of both symbionts changed accumulation of flavonoids in roots. Daidzein and coumestrol increased with plant growth. However, development of the tripartite symbiosis caused a decrease in coumestrol; accumulation of daidzein, the most abundant flavonoid, was reduced in the presence of AMF.
\end{abstract}

(C) 2005 Elsevier Ltd. All rights reserved.

Keywords: Tripartite symbiosis; Signalling; Flavonoids; Arbuscular mycorrhizal fungi; Rhizobia; Soybean; Early interaction; Legume

\section{Introduction}

The interaction between arbuscular mycorrhizal fungi (AMF), B. japonicum and soybean (Glycine $\max (\mathrm{L}$.$) Merr.)$ results in a tripartite mutualistic symbiosis (e.g. El-Hassanin and Lynd, 1985). Biological nitrogen $\left(\mathrm{N}_{2}\right)$ fixation is generally greater than in non-mycorrhizal plants, with more nodules having a greater total dry weight. The effect on nodule number and weight has been a constant feature, detectable 10 days after emergence. This early effect on

\footnotetext{
* Corresponding author. Current address: Department of Integrative Biology, University of Guelph, Guelph, Ont., Canada, N1G2W1 Tel.: + 15198244120 , ext. 56718.

E-mail address: pantunes@uoguelph.ca (P.M. Antunes).
}

0038-0717/\$ - see front matter (c) 2005 Elsevier Ltd. All rights reserved. doi:10.1016/j.soilbio.2005.09.016 nodulation occurs before any transport of phosphorus $(\mathrm{P})$ (Goss and de Varennes, 2002) or zinc (Zn) (Antunes et al., in press) takes place from the soil to the plant. The establishment of these plant-microbial symbioses overcomes the plant defence response through common pathways (see review by Antunes and Goss, 2005), and signalling is more likely to regulate the tripartite symbiosis in its early stages than increased nutrition. Antunes et al. (in press) concluded that daidzein, genistein and coumestrol were key signal compounds associated with the establishment of the tripartite symbiosis. On the other hand, as glycitein and formononetin were not detected in the root tissue, they were not considered important at this early stage. However, these compounds may be more important where there is excessive soil $\mathrm{P}$ or if a pathogen is active in the rhizosphere as they have been associated with plant defence mechanisms (e.g. Morris et al., 1991; Edwards 
et al., 1995; Landini et al., 2003). Moreover, formononetin concentration was increased in P-treated alfalfa inoculated with Glomus intraradices, even in the absence of any root colonization (Volpin et al., 1994). Antunes et al. (in press) also found that at 10 days after plant emergence the concentrations of daidzein and coumestrol in the root were elevated relative to those in the seed, whereas the concentration of genistein in the root was smaller than that in the seed. Importantly, the root concentrations of these signal compounds were greater in plants under a soil disturbance treatment that resulted in less colonization by either AMF or B. japonicum. However, it was unclear whether soil disturbance induced changes in root accumulation of flavonoids other than through changing the potential for AMF colonization. Consequently, we have investigated whether (1) modification of flavonoid accumulation in soybean roots depends on the potential for AMF colonization of the soil, and (2) synthesis and accumulation of flavonoids in the roots change over time as a function of early plant-microbial interactions and the development of the tripartite symbiosis.

\section{Materials and methods}

\subsection{Soil and growing conditions}

The experiment was conducted under controlled environment conditions, set for a $16 \mathrm{~h}_{\text {days }}^{-1}$ at $25^{\circ} \mathrm{C}$ with a light intensity of $250 \mu \mathrm{mol} \mathrm{s}{ }^{-1} \mathrm{~m}^{-2}$, and $8 \mathrm{~h}$ night at $18^{\circ} \mathrm{C}$. To maximize the visible light spectrum, a combination of three different types of $215 \mathrm{~W}$ fluorescent lamps (Sylvania Cool White F96T12/CW/VHO, Industrial F96T12/GL/WS/VHO and Vitalux Duro-Test F96T-12) and regular $40 \mathrm{~W}$ incandescent lamps were used. Infestation by thrips, mites and fungus gnats was prevented by using their respective mite predators Amblyseius cucumeris, Phytoseiulus persimilis and Hypoaspis miles. These biological control agents were applied to the leaves as larvae in a sawdust medium.

Soil, a fine sandy loam, was collected on 20 July 2003 from the top $20 \mathrm{~cm}$ of an arable field on a farm near Belwood $\left(43^{\circ} 45^{\prime} \mathrm{N} 80^{\circ} 15^{\prime} \mathrm{W}\right)$, Ontario, Canada, where there was no record of soybean being grown previously. The soil was broken up mechanically, sieved $(4 \mathrm{~mm})$ and stored under cover at ambient temperature. Samples were taken for analysis of $2.0 \mathrm{M}$ $\mathrm{KCl}$-extractable $\mathrm{NH}_{4}-\mathrm{N}$ and $\mathrm{NO}_{3}-\mathrm{N}$ (Keeney and Nelson, 1982), 0.5 M NaHCO 3 -extractable $\mathrm{P}$ (Olsen and Summers, 1982), $1.0 \mathrm{M}$ ammonium-acetate extractable $\mathrm{K}$ and $\mathrm{Mg}$ (Knudsen et al., 1982) and pH (1:1 in water). Soybean seeds were sown in pots of the soil, and their failure to nodulate by the time of flowering confirmed the absence of Bradyrhizobium. To eliminate the indigenous population of mycorrhizal fungi, the soil was pasteurized on 8 September 2003 by gradually raising the soil temperature to $80{ }^{\circ} \mathrm{C}$ over a period of $60 \mathrm{~min}$ in an electrical unit, keeping the soil at this temperature for $2 \mathrm{~h}$, and then cooling it gradually. McGonigle and Miller (1996) reported that all mycorrhizal spores and nearly all hyphae in soil pasteurized by this procedure were not viable, and concluded that soil treatments excluding mycorrhizal fungi could be achieved this way. After pasteurization, the soil was stored in covered plastic bins. Prior to use, the soil was analysed for the mineral nutrients described earlier.

\subsection{Preliminary phase}

On 11 September 2003, each of 50 pots (3 1) was packed with the equivalent of $3050 \mathrm{~g}$ of oven-dry soil to a bulk density of approximately $1.3 \mathrm{~g} \mathrm{~cm}^{-3}$. A core $5 \mathrm{~cm}$ dia and $8 \mathrm{~cm}$ long was removed from the centre of each pot. A portion of mycorrhizal inoculum was placed at the bottom of the resulting hole and then re-covered. The inoculum was prepared by thoroughly mixing, in a plastic bag, $150 \mathrm{~g}$ of pasteurized soil with a large concentration of propagules of G. clarum Nicol. \& Schenck (supplied by Dr. Joseph B. Morton, INVAMInternational Culture Collection of (Vesicular) AMF, accession number BR147B) in the form of root fragments of sudangrass (Sorghum bicolour (L.) Moench), hyphae and spores in a 5:1 dilution. The mixture was divided into 50 equal portions with a rotary sampler divider. Pots assigned to non-mycorrhizal treatments were supplied with a similar amount of sterilized inoculum (autoclaved at $121{ }^{\circ} \mathrm{C}$ for $15 \mathrm{~min}$ ) to guarantee similar edaphic conditions in all the treatments. A separate $100 \mathrm{~g}$ sample of mixed inoculum was washed with 21 of $0.1 \%$ (w/v) Bacto-Peptone, and then filtered through a $20 \mu \mathrm{m}$ mesh (Ames et al., 1987). An aliquot of $50 \mathrm{ml}$ of this filtrate was added to each of the 25 pots assigned to non-mycorrhizal treatments to supply the soil with microbial populations of nonmycorrhizal organisms present in the mycorrhizal inoculum. Even though soil pasteurization has been shown to be an effective method of eliminating AMF, it does not provide sterilization. Therefore, it was assured that all treatments contained identical populations of indigenous and inoculant non-mycorhizal microorganisms.

Each of the 50 pots was planted with three maize seedlings (Zea mays L. cv. Pioneer 3905). The seeds were initially surfaced-sterilized (95\% alcohol for $1 \mathrm{~min}$ ), rinsed thoroughly with deionised water, and germinated in sterilized (autoclaved at $121{ }^{\circ} \mathrm{C}$ for $15 \mathrm{~min}$ ) moist vermiculite. The soil gravimetric water content was initially made up to approximately $200 \mathrm{mg}$ $\mathrm{H}_{2} \mathrm{O} \mathrm{g}^{-1}$ dry soil and then restored to that level by irrigating with deionised water every second day. The pots were completely randomized prior to each irrigation. Seedlings produced the coleoptile leaf on 15 September 2003. The plants were then thinned to two per pot. On 2 October 2003, 3 weeks after emergence, all shoots were excised and a new 3-week growth period was started 1 day later. At the end of the second 3-week growth period, on 27 October 2003, root samples were collected from two pots (each taken from a different mycorrhizal treatment), carefully washed out of the soil, fixed in formyl acetic alcohol, cleared in $\mathrm{KOH}$, and stained with chlorazol-black E (Brundrett et al., 1984) before being examined for AMF colonization with the line-intersect method described by McGonigle et al. (1990). Soil samples collected in these pots underwent the nutrient analysis described earlier. 


\subsection{Tripartite symbiosis study phase}

The second phase of the experiment consisted of growing soybean in the remaining 48 pots (each pot being an experimental unit); these pots were inoculated with all possible combinations of each microsymbiont, with the objective of studying changes in flavonoid concentration in the plant during the early stages of mycorrhizal and bradyrhizobial colonization. The experiment was comprised of four inoculum treatments ( $G$. clarum, B. japonicum, G. clarum and $B$. japonicum, Non-inoculated control) and four sampling dates (at 6, 10, 14 and 40 days after emergence,) arranged in a completely randomized design with three replications.

Sets of 12 soybean seeds (Harovinton) were surfacesterilized (95\% alcohol for $1 \mathrm{~min})$, germinated in sterilized (autoclaved at $121{ }^{\circ} \mathrm{C}$ for $15 \mathrm{~min}$ ) moist vermiculite, and then planted into appropriate pots on 6 November 2003. Inoculation consisted of placing $0.25 \mathrm{~g}$ of peat-based inoculant of $B$. japonicum (Kirchner) Jordan strain 532C (MicroBio, Saskatoon, SK, HiStick +) at the bottom of each small hole, into which each soybean seedling was planted. The same amount of sterilized inoculant (autoclaved at $121{ }^{\circ} \mathrm{C}$ for $15 \mathrm{~min}$ ) was also placed at the bottom of each seedling hole in pots assigned to treatments without B. japonicum, so that edaphic conditions around the newly formed radicles were similar in all the treatments.

Soybean plants from randomly selected pots of each treatment were harvested 6 days after emergence, on 12 November 2003. The height and wet weight of the shoots were determined. The shoots were then freeze-dried (Labconco Freeze Dryer 18), weighed, and finely ground with a mortar and pestle for analysis of their $\mathrm{N}$ and $\mathrm{P}$ content (Thomas et al., 1967). The digests were also analysed for Zn by Flame Atomic Absorption Spectrometry (F-AAS; model SpectraAA-300) (Richards, 1993). For each pot, all root systems were carefully washed out of the soil, weighed, and fixed in formyl acetic alcohol before being stained and examined for AMF colonization, as described above. The remaining roots were freeze-dried, sectioned with scissors and finely ground in a mortar and pestle for analysis of glycitein, daidzein, genistein, coumestrol and formononetin. Concentrations of flavonoids were determined using a high-performance liquid chromatography (HPLC) method modified from Franke et al. (1995) (see Antunes et al., in press). All root systems were carefully examined for nodules and those visible with the aid of a stereoscopic microscope were counted.

Other plants were selected and harvested at 10 and 14 days after emergence (16 November 2003 and 20 November 2003, respectively). These plants underwent the same analysis described for the 6 days old plants.

The final group of soybean plants were grown to flowering, to determine the effect of the tripartite symbiosis on $\mathrm{N}_{2}$ fixation. After harvesting the 14 day-old plants, soybean plants in the remaining 12 pots were thinned to four plants per pot. Then, $50 \mathrm{ml}$ of a solution of ${ }^{15} \mathrm{NH}_{4}^{15} \mathrm{NO}_{3}, 29.9 \mathrm{mM}$ at $10.6 \%$ ${ }^{15} \mathrm{~N}$, which corresponds to a rate of approximately $30 \mathrm{~kg} \mathrm{~N} \mathrm{ha}^{-1}$, were added to each of those pots. According to Goss et al. (2002), such a fertilizer application rate is not likely to affect nodulation. To avoid direct absorption of ${ }^{15} \mathrm{~N}$ by the shoot, care was taken to prevent direct contact between the solution and the plants during the procedure. To facilitate the incorporation and distribution of ${ }^{15} \mathrm{~N}, 100 \mathrm{ml}$ of water were then added to each pot.

Forty days after emergence, on 15 December 2003, the shoots were harvested and their height measured. They were then oven-dried at $60{ }^{\circ} \mathrm{C}$ for $48 \mathrm{~h}$ and weighed. The shoots were first finely ground in a model 3 Wiley Mill (Thomas Scientific, Swedesboro, NJ) and then pulverized in a MM300 Brinkman Retsch sphere mill for analysis of their total $\mathrm{N}$ content and for the ratio of ${ }^{14} \mathrm{~N}:{ }^{15} \mathrm{~N}$, by mass spectrometry (Mulvaney, 1993). The $\mathrm{N}_{2}$ fixation was estimated by the difference method and by the isotopic dilution method. For the difference method, the total $\mathrm{N}$ content of non-inoculated control plants (derived from soil) was subtracted from the total $\mathrm{N}$ content of inoculated plants (derived from soil and atmosphere). For the isotopic dilution method, $\mathrm{N}_{2}$ fixation was assessed based on the percentage of $\mathrm{N}$ derived from atmosphere (\% Ndfa), which was calculated according to the Eqs. reported by Fried and Middelboe (1977), with the non-inoculated soybean plants as the non-fixing control. All root systems of each pot were carefully washed out of the soil, and a portion was fixed in formyl acetic alcohol before being examined for AMF colonization as described earlier. The remaining root tissue was prepared for analysis of flavonoids as described above. Prior to grinding the root material, nodules were counted and the total for each plant weighed before being reincorporated into each appropriate sample for flavonoid analysis.

\subsection{Statistical analysis}

For the initial phase of maize growth periods, comparisons between means were made using $t$-tests for independent samples. Results from the tripartite symbiosis study phase were examined by analysis of variance (ANOVA) for a completely randomized design (CRD). To examine differences within each treatment over time, a repeated measures ANOVA was performed. The Shapiro-Wilk's $W$ test was used to determine whether or not the observations followed a normal distribution (Shapiro et al., 1968). The assumption of homogeneity of variances was confirmed by the Levene's test (Conover et al., 1981). Non-homogenous data were analysed with the Kruskal-Wallis non-parametric test (Kruskal and Wallis, 1952). This test assesses the data by ranking them; therefore, no assumptions were made.

Unless otherwise specified, when the F-test of the treatment mean square indicated that there were significant variances due to treatment effects, means were compared using the Tukey's HSD (honest significant difference) test $(P<0.05)$ (Tukey, 1949). Tests were performed using the computer software package STATISTICA for the Microsoft Windows operating system (StatSoft, Inc., 1995). 
Table 1

Soil concentrations of $\mathrm{NH}_{4}-\mathrm{N}, \mathrm{NO}_{3}-\mathrm{N}, \mathrm{P}, \mathrm{K}, \mathrm{Mg}$ and soil $\mathrm{pH}$ prior to use, after pasteurization and after conclusion of the second 3-week growth period of maize (values in parentheses represent SEM)

\begin{tabular}{llll}
\hline & \multicolumn{2}{l}{ Soil nutrient content } \\
\cline { 2 - 4 } & $\begin{array}{l}\text { Prior to pas- } \\
\text { teurization }\end{array}$ & $\begin{array}{l}\text { After pasteuri- } \\
\text { zation }\end{array}$ & $\begin{array}{l}\text { After 2 periods } \\
\text { of maize growth }\end{array}$ \\
\hline $\mathrm{NH}_{4}-\mathrm{N}\left(\mathrm{mg} \mathrm{kg}^{-1}\right)$ & $5.1(1.50) \mathrm{c}$ & $50.3(0.01) \mathrm{a}$ & $36.3(1.32) \mathrm{b}$ \\
$\mathrm{NO}_{3}-\mathrm{N}\left(\mathrm{mg} \mathrm{kg}^{-1}\right)$ & $9.0(0.21) \mathrm{b}$ & $12.4(0.23) \mathrm{a}$ & $3.5(0.07) \mathrm{c}$ \\
$\mathrm{P}\left(\mathrm{mg} \mathrm{kg}^{-1}\right)$ & $47.0(0.58) \mathrm{b}$ & $53.7(2.19) \mathrm{a}$ & $43.0(0.71) \mathrm{c}$ \\
$\mathrm{K}\left(\mathrm{mg} \mathrm{kg}^{-1}\right)$ & $138.7(0.88) \mathrm{b}$ & $202.3(11.35) \mathrm{a}$ & $106.5(2.99) \mathrm{c}$ \\
$\mathrm{Mg}\left(\mathrm{mg} \mathrm{kg}^{-1}\right)$ & $146.3(2.33) \mathrm{b}$ & $161.7(5.70) \mathrm{a}$ & $158.0(1.35) \mathrm{a}$ \\
$\mathrm{pH}\left(1: 1 \mathrm{in} \mathrm{water}^{-1}\right)$ & $6.8(0.03) \mathrm{a}$ & $6.8(0.06) \mathrm{a}$ & $6.8(0.05) \mathrm{a}$ \\
\hline
\end{tabular}

Values in a row followed by the same letter are not significantly different $(P<0.05)$.

\section{Results}

\subsection{Preliminary phase}

Soil $\mathrm{NH}_{4}-\mathrm{N}$ increased 10 -fold and $\mathrm{NO}_{3}-\mathrm{N}$ increased by nearly $40 \%$ due to pasteurization (Table 1 ). After two growth periods of maize, $\mathrm{NH}_{4}-\mathrm{N}$ and $\mathrm{NO}_{3}-\mathrm{N}$ had been reduced by approximately 30 and $70 \%$, respectively. The concentration of $\mathrm{P}$ was slightly increased by soil heating, but decreased to $43 \mathrm{mg} \mathrm{kg}^{-1}$ at the end of the 3-week growth periods. The $\mathrm{pH}$ of the soil was 6.8 , and was unaffected by the pasteurization.

In the last growth period for maize, plants from soil inoculated with $G$. clarum had significant amounts of mycorrhizal colonization (Fig. 1). On the other hand, no arbuscules or vesicles were found in roots from non-inoculated pots, and only trace quantities of mycorrhizal hyphae were detected. Appropriate treatments necessary to test the hypotheses were, therefore, established and the second phase of the study was initiated.

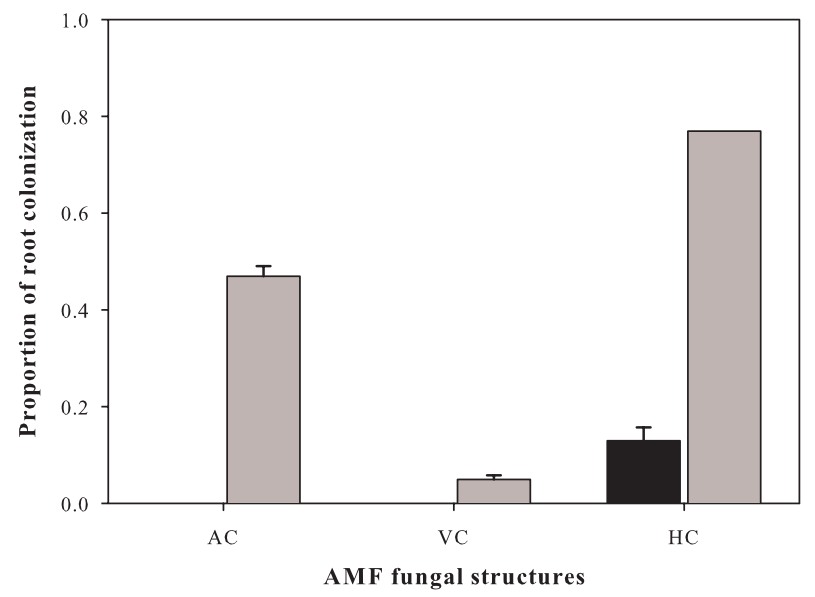

Fig. 1. Proportion of root length containing mycorrhizal fungal arbuscules (AC), vesicles (VC) and hyphae (HC) in maize plants grown in inoculated (G. clarum) (grey bars) or pasteurized (black bars) soil after a second period of 3 weeks (values in parentheses represent standard error of the mean). Error bars are SEM.

\subsection{Tripartite symbiosis study phase}

\subsubsection{Plant growth and nutrition}

The dry weight increase was the same for soybean plants of all treatments up to 14 days after emergence (Table 2). However, by that time there was less $\mathrm{P}$ and $\mathrm{Zn}$ in plants without AMF. The concentrations of $\mathrm{P}$ and $\mathrm{Zn}$ in plants colonized solely by $B$. japonium were 17 and $11 \%$, respectively, smaller than those for plants colonized by G. clarum, regardless of the presence of the bacterial symbiont. At 40 days after emergence, the plants had flowered, and B. japonicum had promoted mass increase by $35 \%$ and improved $\mathrm{N}$ nutrition approximately 2.6 times (Table 2). The increase in $\mathrm{N}$ was greater by a further $18 \%$ when the fungal symbiont was also present ( $G$. clarum and $B$. japonicum).

\subsubsection{Root colonization by $A M F$ and B. japonicum}

The absence of arbuscules and vesicules in non-inoculated maize plants was also maintained in soybean plants of the noninoculated control and B. japonicum treatments. Only very few roots were colonized by fungal hyphae in these treatments (Table 3). Furthermore, up to 14 days after emergence no nodules were observed in plants grown in soil to which no B. japonicum was added. However, at flowering some nodules were detected in those treatments, although numbers were very small compared with those in the inoculated treatments.

The presence of B. japonicum had no effect on AMF colonization at any stage of plant development. Conversely, the presence of the fungus stimulated nodule development. No differences in numbers were observed 10 days after emergence, but 4 days later, soybean plants inoculated with both G. clarum and $B$. japonicum had $30 \%$ more nodules, that combined were $42 \%$ heavier than nodules on plants inoculated with only the bacterial symbiont. The presence of the mycorrhizal fungus continued to affect $B$. japonicum up to flowering, when the differences in the number became non-significant, but the difference in nodule weight increased from 42 to $50 \%$.

\subsubsection{Accumulation of flavonoids in soybean roots}

For each of the flavonoids investigated, the concentration and content in the roots of soybean plants was the same in all treatments up to 10 days after emergence (Table 4). Formononetin was not detected at any stage of plant development. At 6 days after emergence, the concentration of daidzein and glycitein was at least four and two times greater, respectively, in the root than in the seed (data not shown). Coumestrol, which was not detected in the seed, had accumulated to a concentration greater than $1000 \mathrm{\mu g} \mathrm{g}^{-1}$. In contrast, the concentration of genistein was approximately three times smaller in the root than that in the seed.

The accumulation of daidzein and genistein in roots of plants inoculated with both G. clarum and B. japonicum reached a maximum sooner than in plants from other treatments. By 14 days after emergence, the accumulation of daidzein and genistein was approximately $40 \%$ less in plants inoculated with both $G$. clarum and B. japonicum than in plants under other treatments. However, a similar reduction in 
Table 2

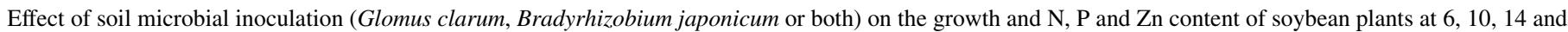
40 days after emergence (values in parentheses represent SEM)

\begin{tabular}{|c|c|c|c|c|c|}
\hline Soil treatment & Days after emergence & Shoot weight (g plant ${ }^{-1}$ ) & $\mathrm{N}$ content (mg plant ${ }^{-1}$ ) & $\mathrm{P}$ content (mg plant ${ }^{-1}$ ) & $\mathrm{Zn}$ content $\left(\mu \mathrm{g}_{\text {plant }}{ }^{-1}\right)$ \\
\hline Control & 6 & $0.2(0.01) \mathrm{a}$ & $14.9(0.98) \mathrm{a}$ & $1.2(0.10) \mathrm{a}$ & $10.4(0.87) \mathrm{a}$ \\
\hline G. clarum & & $0.2(0.003) \mathrm{a}$ & $15.4(0.34) \mathrm{a}$ & $1.2(0.07) \mathrm{a}$ & $10.7(0.47) \mathrm{a}$ \\
\hline B. japonicum & & $0.2(0.01) \mathrm{a}$ & $15.0(0.67) \mathrm{a}$ & $1.2(0.07) \mathrm{a}$ & $9.8(0.65) \mathrm{a}$ \\
\hline Glom. + Brad. & & $0.2(0.01) \mathrm{a}$ & $16.0(0.21) \mathrm{a}$ & $1.3(0.06) \mathrm{a}$ & $10.6(0.41) \mathrm{a}$ \\
\hline Control & 10 & $0.3(0.01) \mathrm{a}$ & $17.5(0.29) \mathrm{a}$ & $1.4(0.02) a b$ & $14.3(0.44) \mathrm{ab}$ \\
\hline G. clarum & & $0.3(0.01) \mathrm{a}$ & $18.3(0.75) \mathrm{a}$ & $1.5(0.05) \mathrm{a}$ & $15.9(0.40) \mathrm{a}$ \\
\hline B. jаропісит & & $0.3(0.01) \mathrm{a}$ & $16.2(0.44) \mathrm{a}$ & $1.3(0.04) b$ & $12.7(0.36) \mathrm{b}$ \\
\hline Glom. + Brad. & & $0.3(0.01) \mathrm{a}$ & $17.8(0.75) \mathrm{a}$ & $1.5(0.01) \mathrm{a}$ & $14.8(0.55) \mathrm{a}$ \\
\hline Control & 14 & $0.3(0.01) \mathrm{a}$ & $13.2(0.21) b$ & $1.5(0.05) \mathrm{b}$ & $15.8(0.43) \mathrm{ab}$ \\
\hline G. clarum & & $0.3(0.01) \mathrm{a}$ & $14.7(0.73) \mathrm{ab}$ & $1.7(0.06) \mathrm{a}$ & $18.2(0.84) \mathrm{a}$ \\
\hline B. japonicum & & $0.3(0.01) \mathrm{a}$ & $13.1(0.51) b$ & $1.3(0.07) \mathrm{b}$ & $13.4(0.65) \mathrm{b}$ \\
\hline Glom. + Brad. & & $0.3(0.02) \mathrm{a}$ & $15.9(0.55) \mathrm{a}$ & $1.8(0.10) \mathrm{a}$ & $17.8(0.91) \mathrm{a}$ \\
\hline Control & 40 & $1.6(0.04) \mathrm{b}$ & $16.5(0.71) \mathrm{c}$ & ND & ND \\
\hline G. clarum & & $1.8(0.06) \mathrm{b}$ & $16.9(1.22) \mathrm{c}$ & ND & ND \\
\hline B. japonicum & & $2.2(0.08) \mathrm{a}$ & $59.7(0.27) \mathrm{b}$ & ND & ND \\
\hline Glom. + Brad. & & $2.3(0.03) \mathrm{a}$ & $66.5(1.01) \mathrm{a}$ & ND & ND \\
\hline
\end{tabular}

For each sampling period, means in a column followed by the same letter are not significantly different $(P<0.05)$. ND-Not determined.

daidzein was detected when plants were only inoculated with G. clarum. At flowering, the concentration of genistein was greater in plants from the control and G. clarum treatments than in plants that developed nodules (Table 4). The root content of coumestrol at 14 days after emergence was least in plants inoculated with both microsymbionts. The root accumulation of glycitein was the same, irrespective of treatment, and the root concentration of this isoflavone declined by approximately half between 6 and 10 days after emergence, and it was not detected 4 days after that.

Overall, the root content of daidzein was reduced whenever G. clarum was present, whereas genistein and coumestrol only decreased appreciably in plants inoculated with both microbial symbionts (Table 4 and Fig. 2).

\section{3. $\mathrm{N}_{2}$ fixation at flowering}

As there were very few nodules on the roots of plants grown in non-inoculated soil or in soil solely inoculated with G. clarum (Table 3) only trace amounts of $\mathrm{N}$ were derived from the atmosphere by plants from those treatments (Table 5). Inoculating with the fungus alone did not improve $\mathrm{N}$ nutrition in comparison with the non-inoculated control. In contrast, plants inoculated only with B. japonicum derived $67 \%$ of their $\mathrm{N}$ from the atmosphere and accumulated $43 \mathrm{mg}$ more $\mathrm{N}$ than did the non-inoculated controls. Inoculation with both $G$. clarum and $B$. japonicum increased $\mathrm{N}$-accumulation by an additional $18 \%$ and $\mathrm{N}$ derived from the atmosphere by $7 \%$, resulting in a $23 \%$ increase in $\mathrm{N}_{2}$ fixed. There was a strong

Table 3

Effect of soil inoculation treatment on the proportion of root length containing mycorrhizal fungal arbuscules, vesicles and hyphae, and on nodule formation in soybean plants between $6,10,14$ and 40 days after emergence (values in parentheses represent SEM)

\begin{tabular}{|c|c|c|c|c|c|c|}
\hline \multirow[t]{2}{*}{ Soil treatment } & \multirow{2}{*}{$\begin{array}{l}\text { Days after } \\
\text { emergence }\end{array}$} & \multicolumn{3}{|c|}{ AMF colonization $(\times 100)$} & \multicolumn{2}{|l|}{ Nodules } \\
\hline & & $\begin{array}{l}\text { Arbuscular } \\
\text { colonization }\end{array}$ & $\begin{array}{l}\text { Vesicular } \\
\text { colonization }\end{array}$ & $\begin{array}{l}\text { Hyphal } \\
\text { colonization }\end{array}$ & $\begin{array}{l}\text { Number nodules } \\
\text { plant }^{-1}\end{array}$ & $\begin{array}{l}\text { Dry weight mg } \\
\text { plant }^{-1}\end{array}$ \\
\hline Control & 6 & 0 & 0 & $2(0.5) b$ & 0 & ND \\
\hline G. clarum & & $11(4.1) \mathrm{a}$ & $2(0.2)$ & $45(5.0) \mathrm{a}$ & 0 & ND \\
\hline B. japonicum & & 0 & 0 & 0 & $7.1(0.27) a$ & ND \\
\hline Glom. + Brad. & & $5(1.3) \mathrm{a}$ & 0 & $40(8.2) \mathrm{a}$ & $7.0(0.19) \mathrm{a}$ & ND \\
\hline Control & 10 & 0 & 0 & $1(0.7) \mathrm{b}$ & 0 & ND \\
\hline G. clarum & & $58(2.4) \mathrm{a}$ & $1(0.2) \mathrm{a}$ & $78(5.2) \mathrm{a}$ & 0 & ND \\
\hline B. japonicum & & 0 & 0 & $1(0.4) b$ & $15.7(0.61) \mathrm{a}$ & ND \\
\hline Glom. + Brad. & & $61(9.0) \mathrm{a}$ & $0.4(0.21) \mathrm{a}$ & $82(3.1) a$ & $15.5(0.75) \mathrm{a}$ & ND \\
\hline Control & 14 & 0 & 0 & 0 & 0 & 0 \\
\hline G. clarum & & $62(3.7) a$ & $2(0.3) \mathrm{a}$ & $82(3.5) \mathrm{a}$ & 0 & 0 \\
\hline B. japonicum & & 0 & 0 & $1(1.2) \mathrm{b}$ & $27.5(1.93) b$ & $11.7(0.94) b$ \\
\hline Glom. + Brad. & & $60(3.7) \mathrm{a}$ & $2(0.7) a$ & $85(0.5) \mathrm{a}$ & $35.4(0.92) \mathrm{a}$ & $16.6(1.91) \mathrm{a}$ \\
\hline Control & 40 & 0 & 0 & $2(0.8) b$ & $1.4(0.62) \mathrm{b}$ & $12.8(6.10) \mathrm{c}$ \\
\hline G. clarum & & $57(3.4) \mathrm{a}$ & $5(1.5) \mathrm{a}$ & $88(0.9) \mathrm{a}$ & $1.3(1.25) b$ & $2.1(2.05) \mathrm{c}$ \\
\hline B. japonicum & & 0 & 0 & $4(1.5) b$ & $44.0(3.15) \mathrm{a}$ & $98.4(8.14) b$ \\
\hline Glom. + Brad. & & 48 (7.3)a & $5(2.0) \mathrm{a}$ & $86(4.2) \mathrm{a}$ & $51.8(4.99) \mathrm{a}$ & $147.5(2.71) \mathrm{a}$ \\
\hline
\end{tabular}

For each sampling period, means in a column followed by the same letter are not significantly different $(P<0.05)$. ND-not determined. 
Table 4

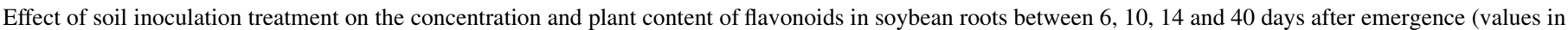
parentheses represent SEM)

\begin{tabular}{|c|c|c|c|c|c|}
\hline \multirow[t]{2}{*}{ Flavonoid } & \multirow[t]{2}{*}{ Treatment } & \multicolumn{4}{|c|}{ Days after emergence } \\
\hline & & 6 & 10 & 14 & 40 \\
\hline \multirow[t]{4}{*}{ Daidzein $\left(\mu \mathrm{g} \mathrm{g}^{-1}\right)$} & Control & 4683 (796)a, $\alpha$ & 3943 (1147)a, $\alpha$ & 6498 (686)ab, $\alpha$ & $6023(802) \mathrm{a}, \alpha$ \\
\hline & G. clarum & 4129 (312)a, $\alpha$ & 4030 (1139)a, $\alpha$ & 5110 (493)ab, $\alpha$ & 6919 (911)a, $\alpha$ \\
\hline & B. japonicum & 2664 (899)a, $\beta$ & $6191(145) \mathrm{a}, \alpha \beta$ & 7034 (463)a, $\alpha$ & 5535 (649)a, $\alpha \beta$ \\
\hline & Glom. + Brad. & 3214 (345)a, $\alpha$ & $5235(351) \mathrm{a}, \alpha$ & 4414 (165)b, $\alpha$ & 4575 (242)a, $\alpha$ \\
\hline \multirow[t]{4}{*}{ Daidzein $\left(\mu\right.$ g plant $\left.^{-1}\right)$} & Control & $231(44) \mathrm{a}, \beta$ & 343 (105)a, $\beta$ & $922(127) \mathrm{a}, \alpha$ & ND \\
\hline & G. clarum & $202(21) \mathrm{a}, \beta$ & $326(84) \mathrm{a}, \alpha \beta$ & $612(55) \mathrm{ab}, \alpha$ & ND \\
\hline & B. japonicum & 128 (44)a, $\beta$ & $514(33) \mathrm{a}, \alpha \beta$ & $855(56) \mathrm{a}, \alpha$ & ND \\
\hline & Glom. + Brad. & 155 (18)a, $\beta$ & $406(64) \mathrm{a}, \alpha$ & $532(11) b, \alpha$ & ND \\
\hline \multirow[t]{4}{*}{ Genistein $\left(\mu \mathrm{g} \mathrm{g}^{-1}\right)$} & Control & $364(67) \mathrm{a}, \alpha$ & $322(100) \mathrm{a}, \alpha$ & 453 (94)ab, $\alpha$ & $545(95) \mathrm{a}, \alpha$ \\
\hline & G. clarum & 354 (15)a, $\beta$ & 355 (92)a, $\beta$ & 465 (41)ab, $\alpha \beta$ & 587 (50)a, $\alpha$ \\
\hline & B. japonicum & 241 (78)a, $\beta$ & $374(60) \mathrm{a}, \alpha \beta$ & 505 (31)a, $\alpha$ & $309(16) b, \alpha \beta$ \\
\hline & Glom. + Brad. & 255 (14)a, $\alpha$ & 453 (73)a, $\alpha$ & 305 (29)b, $\alpha$ & $263(13) b, \alpha$ \\
\hline \multirow[t]{4}{*}{ Genistein $\left(\mu \mathrm{g} \mathrm{plant}^{-1}\right)$} & Control & 18 (3.8)a, $\beta$ & 28 (9.2)a, $\beta$ & 64 (15.0)a, $\alpha$ & ND \\
\hline & G. clarum & 17 (1.3)a, $\beta$ & 29 (6.9)a, $\beta$ & $56(3.8) \mathrm{a}, \alpha$ & ND \\
\hline & B. japonicum & $12(3.8) \mathrm{a}, \beta$ & $30(3.5) \mathrm{a}, \beta$ & 61 (3.7)a, $\alpha$ & ND \\
\hline & Glom. + Brad. & 12 (0.7)a, $\beta$ & 35 (8.3)a, $\alpha$ & $37(2.2) b, \alpha$ & ND \\
\hline \multirow[t]{4}{*}{ Coumestrol $\left(\mu \mathrm{g} \mathrm{g}^{-1}\right)$} & Control & 1261 (114)a, $\beta$ & 2189 (657)a, $\beta$ & 4799 (173)a, $\alpha$ & $5331(537) \mathrm{a}, \alpha$ \\
\hline & G. clarum & 1175 (79)a, $\gamma$ & 2394 (579)a, $\beta \gamma$ & $4660(555) \mathrm{a}, \alpha \beta$ & 5703 (639)a, $\alpha$ \\
\hline & B. japonicum & 881 (263)a, $\beta$ & 2943 (228)a, $\alpha \beta$ & 4279 (275)a, $\alpha$ & 4899 (887)a, $\alpha$ \\
\hline & Glom. + Brad. & 1103 (135)a, $\beta$ & $2320(436) \mathrm{a}, \alpha \beta$ & 3667 (161)a, $\alpha$ & 3887 (429)a, $\alpha$ \\
\hline \multirow[t]{4}{*}{ Coumestrol $\left(\mu \mathrm{g}_{\text {plant }}{ }^{-1}\right)$} & Control & $62(6.8) \mathrm{a}, \beta$ & 190 (60.1)a, $\beta$ & 680 (52.6)a, $\alpha$ & ND \\
\hline & G. clarum & 57 (2.2)a, $\beta$ & 195 (41.7)a, $\beta$ & 556 (58.0)ab, $\alpha$ & ND \\
\hline & B. japonicum & $42(12.8) \mathrm{a}, \beta$ & $246(32.5) \mathrm{a}, \beta$ & $520(29.7) b, \alpha$ & ND \\
\hline & Glom. + Brad. & $53(3.8) \mathrm{a}, \beta$ & 175 (33.0)a, $\beta$ & $443(27.0) \mathrm{b}, \alpha$ & ND \\
\hline \multirow[t]{4}{*}{ Glycitein $\left(\mu \mathrm{g} \mathrm{g}^{-1}\right)$} & Control & $310(44) \mathrm{a}, \alpha$ & 174 (39)a, $\alpha$ & 0 & 0 \\
\hline & G. clarum & 348 (17)a, $\alpha$ & 199 (43)a, $\beta$ & 0 & 0 \\
\hline & B. japonicum & $244(61) \mathrm{a}, \alpha$ & 151 (79)a, $\alpha$ & 0 & 0 \\
\hline & Glom. + Brad. & 303 (33)a, $\alpha$ & 124 (62)a, $\beta$ & 0 & 0 \\
\hline \multirow[t]{4}{*}{ Glycitein $\left(\mu \mathrm{g} \mathrm{plant}^{-1}\right)$} & Control & $15(2.6) \mathrm{a}, \alpha$ & $15(3.8) \mathrm{a}, \alpha$ & 0 & 0 \\
\hline & G. clarum & $17(0.7) \mathrm{a}, \alpha$ & 16 (2.9)a, $\alpha$ & 0 & 0 \\
\hline & B. japonicum & $12(3.0) \mathrm{a}, \alpha$ & $13(7.1) \mathrm{a}, \alpha$ & 0 & 0 \\
\hline & Glom. + Brad. & $15(2.7) \mathrm{a}, \alpha$ & $11(5.2) \mathrm{a}, \alpha$ & 0 & 0 \\
\hline
\end{tabular}

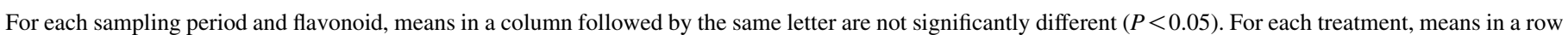
followed by the same Greek letter are not significantly different. ND-not detected; n.a.-not assessed.

relationship between ${ }^{15} \mathrm{~N}$ and $\mathrm{N}$ difference methods of calculating the amount of $\mathrm{N}$ derived from biologically fixed $\mathrm{N}_{2}\left(r^{2}=0.86, P \leq 0.01\right)$.

\section{Discussion}

\subsection{Establishment of the tripartite symbiosis}

When the tripartite symbiosis was established, it resulted in improved nodulation in soybean and greater biological nitrogen fixation. However, the effects on nodulation were not detected earlier than 14 days after plant emergence. In contrast, Goss and de Varennes (2002) and Antunes et al. (in press) detected the effect by 10 days after emergence. Two reasons might explain this discrepancy; either there was a delay in the development of the tripartite symbiosis due simply to variability in plant growth between experiments, or the contribution of G. clarum was somehow different from that of indigenous AMF. G. clarum is considered to have high colonization potential (Dr. Joseph B. Morton, INVAM, pers. comm., Aug 2003), and by 10 days after emergence the proportion of root colonization was as extensive as previously observed for indigenous AMF (Antunes et al., in press). Therefore, unless there are specificities related to signalling among the AMF, the first alternative is more plausible.

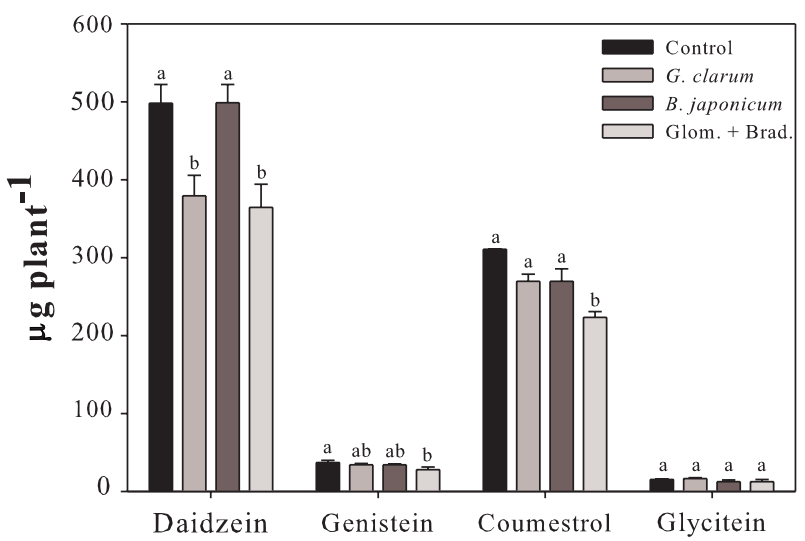

Fig. 2. Effect of inoculation treatment on the overall accumulation of flavonoids in soybean roots across 6,10 and 14 days after emergence. Error bars are SEM. For each flavonoid, means in a bar followed by the same letter are not significantly different $(P<0.05)$. 
Table 5

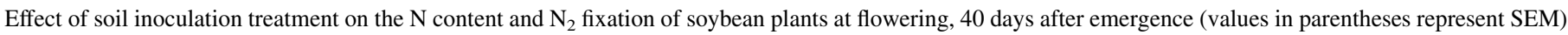

\begin{tabular}{|c|c|c|c|c|}
\hline \multirow[t]{2}{*}{ Measured parameter } & \multicolumn{4}{|c|}{ Soil inoculation treatment } \\
\hline & Control & G. clarum & B. japonicum & Glom.+ Brad. \\
\hline $\mathrm{N}$ concentration $\left(\mathrm{g} \mathrm{kg}^{-1}\right)$ & $10.5(0.19) \mathrm{c}$ & $9.5(0.36) \mathrm{c}$ & $25.7(0.22) \mathrm{b}$ & $30.3(0.70) \mathrm{a}$ \\
\hline $\mathrm{N}$ content $\left(\mathrm{mg} \mathrm{plant}^{-1}\right)$ & $16.5(0.71) \mathrm{c}$ & $16.9(1.22) \mathrm{c}$ & $59.7(0.27) \mathrm{b}$ & $66.5(1.01) \mathrm{a}$ \\
\hline $\mathrm{Ndfa}^{\mathrm{a}}(\%)$ & Trace & Trace & $67.3(1.25) \mathrm{b}$ & $74.2(1.82) \mathrm{a}$ \\
\hline $\mathrm{Ndfs}^{\mathrm{b}}(\%)$ & $29.1(0.36) \mathrm{a}$ & $30.3(1.67) \mathrm{a}$ & $11.8(0.32) \mathrm{b}$ & $10.0(0.46) \mathrm{b}$ \\
\hline $\mathrm{Ndff}^{\mathrm{c}}(\%)$ & $71.9(1.07) \mathrm{a}$ & $75.5(4.91) \mathrm{a}$ & $20.9(0.93) b$ & $15.8(1.36) \mathrm{b}$ \\
\hline $\mathrm{N}_{2}$ fixed (mg plant ${ }^{-1}$ ) & Trace & Trace & $40.2(0.92) \mathrm{b}$ & $49.4(1.86) \mathrm{a}$ \\
\hline $\mathrm{N}_{2}$ fixed $^{\mathrm{d}}\left(\right.$ mg plant $\left.^{-1}\right)$ & Trace & Trace & $36.0(0.06) \mathrm{b}$ & $44.1(0.21) \mathrm{a}$ \\
\hline
\end{tabular}

For each measured parameter, means in a row followed by the same letter are not significantly different $(P<0.05)$.

${ }^{\text {a }}$ Nitrogen derived from the atmosphere.

b Nitrogen derived from soil.

c Nitrogen derived from fertilizer.

d Calculated by the difference method.

It has been assumed that the beneficial effect of mycorrhizal colonization on nodulation is due to an increased supply of $\mathrm{P}$ to the nodules (e.g. Vejsadová et al., 1993; George et al., 1995). Zinc is poorly mobile in soils and is often limiting to plant growth. Furthermore, AMF colonization can increase $\mathrm{Zn}$ uptake by roots at an early stage (Bowen et al., 1974) and decrease deficiency in many species (e.g. Thompson, 1990; Burkert and Robson, 1994). Yadav et al. (1986) demonstrated that $\mathrm{P}$ and $\mathrm{Zn}$ interact significantly and applications at different concentrations consistently increased the number of nodules, nodule weight, leghaemoglobin content and $\mathrm{N}_{2}$ fixation. Goss and de Varennes (2002) and Antunes et al. (in press) suggested that the uptake of $\mathrm{P}$ or $\mathrm{Zn}$ from soil was not important for the development of the interaction between AMF and B. japonicum. In this study, by 14 days after emergence the concentration of $\mathrm{P}$ and $\mathrm{Zn}$ was smaller in the shoots of plants solely colonized by $B$. japonicum than in shoots of plants in other treatments, suggesting that these elements were taken up from the soil by the plant through the mycorrhizal hyphae. However, that does not necessarily explain the increase in the number and weight of the nodules in plants colonized by both microbial symbionts. The concentrations of $\mathrm{P}$ and $\mathrm{Zn}$ in all the soybean plants appeared to be above the critical values at this time, which means that $\mathrm{P}$ and $\mathrm{Zn}$ could be allocated to the formation of nodules without constraint. Therefore, the interpretation that the establishment of the tripartite symbiosis is not regulated by increased $\mathrm{P}$ or $\mathrm{Zn}$ uptake is re-affirmed.

\subsection{The significance of flavonoid accumulation in roots}

\subsubsection{Daidzein, genistein and coumestrol}

During the early stages of plant development the much greater concentrations of daidzein and coumestrol in the root than in the seed were similar to those reported by Antunes et al. (in press). Nonetheless, by 14 days after emergence, the accumulation of daidzein in plant roots colonized by both B. japonicum and G. clarum was less than that in plants without mycorrhizas. Since the overall content of daidzein in roots of mycorrhizal plants was smaller than that in non-mycorrhizal plants, the AMF appeared to be largely responsible for this response.
The roots of non-inoculated control plants accumulated daidzein to the same extent as plants inoculated only with B. japonicum. Trebovac Stojkov (unpublished, M.Sc. thesis, University of Guelph, 2004) reported amounts of daidzein in roots of 10 days-old soybean plants grown in vermiculite that were similar to the concentrations we found in our control treatment. In the cases of genistein and coumestrol we found that the accumulation in control roots was the same as in soybean plants inoculated with each microsymbiont separately. It can be hypothesised that soybean plants translocate from the seed and synthesise flavonoids, that accumulate in the roots as a function of the development of the latter. Furthermore, the synthesis and accumulation is triggered or influenced by the presence of rhizosphere microorganisms. Soil pasteurization does not ensure complete elimination of AMF and we lack information on the critical amount of specific flavonoid inducers ('Myc factor' or pathogen signal) in the rhizosphere. Given that regulation of nod genes in B. japonicum results from the release of flavonoids from soybean roots (Pueppke et al., 1998; Schmidt et al., 1994), it seems evident that changes in accumulation are probably due to loss through exudation, and appear to be the pivotal mechanism by which these early interactions between all three symbionts are regulated.

The concentration of genistein was three times smaller in the root than in the seed, which is consistent with the results reported by Antunes et al. (in press). However, root accumulation of genistein in plants colonized by both $B$. japonicum and G. clarum was smaller than that of plants under other soil inoculation treatments. Although genistein is present in the root at much smaller concentrations than daidzein, its effectiveness as a signal appears to be important for the establishment of the tripartite symbiosis, most likely through association with nodule formation. Of the commercial flavonoids used by Xie et al. (1995) to study their effect on mycorrhizal colonization in soybean, genistein was the only one that did not produce a stimulatory outcome. Given the difference between the seed and root content of genistein, it is possible that this compound is released into the rhizosphere earlier than are daidzein and coumestrol.

Coumestrol is capable of stimulating hyphal growth and root colonization (Morandi et al., 1992; Xie et al., 1995) as well 
as inducing nod genes in Bradyrhizobium (e.g. Kosslak et al., 1987). Although absent in the seed, coumestrol was synthesized and accumulated in very appreciable amounts in the root. Even though it was not possible to determine whether or not AMF played a key role in the induction of its synthesis as suggested by Larose et al. (2002), given that the concentration of coumestrol was smaller in roots of plants colonized by both AMF and B. japonicum, exudation of this signal compound appears to have resulted mainly from the development of the tripartite symbiosis. Coumestrol, together with daidzein and genistein, are therefore likely to play a key role in the establishment of the tripartite symbiosis.

\subsubsection{Glycitein and formononetin}

The root concentration of the isoflavone glycitein was double that of the seed by 6 days after emergence. The content of the roots then halved by 10 days after emergence, before AMF colonization was fully established, and declined to undetectable amounts by 14 days after emergence. Antunes et al. (in press) did not detect the compound in their study. There are no reports in the literature linking AMF and glycitein, and this isoflavone has been reported to be inactive in inducing nod genes in rhizobia (Pueppke et al., 1998). This compound is, therefore, more likely to be associated with plant defence mechanisms (e.g. Morris et al., 1991; Landini et al., 2003) rather than playing a role in the establishment of the tripartite symbiosis.

Formononetin has been suggested to be associated with an auto-regulation of the mycorrhizal symbiosis at a later phase of development when a large number of arbuscules have already collapsed (Larose et al., 2002). However, we did not detect formononetin in any roots in this study. Perhaps soybean plants are less able to auto-regulate AMF colonization than alfalfa, or they use a different signal compound.

\subsection{The tripartite symbiosis at flowering}

Although the present study was mostly focused on the early stages of growth, the effectiveness of the early tripartite symbiosis in enhancing $\mathrm{N}_{2}$ fixation confirmed reports from other laboratory studies (e.g. Barea et al., 1992; Vejsadová et al., 1993; Goss and de Varennes, 2002). The changes in the signalling patterns that lead to an enhanced nodulation in soybean plants colonized by both AMF and Bradyrhizobium increased $\mathrm{N}_{2}$ fixation at flowering, compared to plants grown in soil inoculated only with B. japonicum. This result further highlights the potential of the tripartite symbiosis to enhance the growth of grain legumes and provide more $\mathrm{N}$ to following crops (Karpenstein-Machan and Stuelpnagel, 2000; Goss et al., 2002).

\section{Acknowledgements}

Support for this work was obtained from the Government of Portugal through the Foundation for Science and Technology, and from the European Union through FEDER. The authors thank Julia Zilka and Miranda Labbe for invaluable technical support.

\section{References}

Ames, R.N., Mihara, K.L., Bethlenfalvay, G.J., 1987. The establishment of microorganisms in vesicular-arbuscular mycorrhizal and control treatments. Biology \& Fertility of Soils 3, 217-223.

Antunes, P.M., Goss, M.J., 2005 Communication in the tripartite symbiosis formed by arbuscular mycorrhizal fungi, rhizobia and legume plants: a review. Chapter 11 in: S.F. Wright and R.W. Zobel (Eds.), Roots and Soil Management: Interactions between Roots and the Soil. Agronomy Monograph No 48. ASA, CSSA, and SSSA, Madison, WI, pp. 199-222.

Antunes, P.M., Rajcan, I, Goss, M.J., in press. Specific flavonoids as interconnecting signals in the tripartite symbiosis formed by arbuscular mycorrhizal fungi, Bradyrhizobium japonicum (Kirchner) Jordan and soybean (Glycine max (L.) Merr.). Soil Biology \& Biochemistry. (Available online, doi:10.1016/j.soilbio.2005.06.008).

Barea, J.M., Azcon-Aguilar, R., Azcon-Aguilar, C., 1992. Vesicular-arbuscular mycorrhizal fungi in nitrogen-fixing systems. In: Norris, J.R., Read, D.J., Varma, A.K. (Eds.), Methods in Microbiology: Techniques for the Study of Mycorrhizae. Academic Press, San Diego, pp. 391-416.

Bowen, G.D., Skinner, M.F., Bevege, D.I., 1974. Zinc uptake by mycorrhizal and uninfected roots of Pinus radiata and Araucaria cunninghamii. Soil Biology \& Biochemistry 6, 141-144.

Brundrett, M.C., Piché, Y., Peterson, R.L., 1984. A new method for observing the morphology of vesicular-arbuscular mycorrhizae. Canadian Journal of Botany 62, 2128-2134.

Burkert, B., Robson, A.D., 1994. ${ }^{65} \mathrm{Zn}$ uptake in subterranean clover (Trifolium subterraneum $\mathrm{L}$.) by three vesicular-arbuscular mycorrhizal fungi in a rootfree sandy soil. Soil Biology \& Biochemistry 26, 1117-1124.

Conover, W.J., Johnson, M.E., Johnson, M.M., 1981. A comparative study of tests of homogeneity of variances, with applications to the outer continental shelf bidding data. Technometrics 23, 351-361.

Edwards, R., Mizen, T., Cook, R., 1995. Isoflavonoid conjugate accumulation in the roots of lucerne (Medicago sativa) seedlings following infection by the stem nematode (Ditylenchus dipsaci). Nematologica 41, 51-66.

El-Hassanin, A.S., Lynd, J.Q., 1985. Soil fertility effects with tripartite symbiosis for growth, nodulation and nitrogenase activity of Vicia faba L. Journal of Plant Nutrition 8, 491-504.

Franke, A.A., Custer, L.J., Cerna, C.M., Narala, K., 1995. HPLC analysis of dietary phytoestrogens from legumes and from human urine. Proceedings of the Society for Experimental Biology and Medicine 203, 16-26.

Fried, M., Middelboe, V., 1977. Measurement of amount of nitrogen fixed by a legume crop. Plant \& Soil 47, 713-715.

George, E., Marschner, H., Jakobsen, I., 1995. Role of arbuscular mycorrhizal fungi in uptake of phosphorus and nitrogen from soil. Critical Reviews in Biotechnology 15, 257-270.

Goss, M.J., de Varennes, A., 2002. Soil disturbance reduces the efficacy of mycorrhizal associations for early soybean growth and N2 fixation. Soil Biology \& Biochemistry 34, 1167-1173.

Goss, M.J., de Varennes, A., Smith, P.S., Ferguson, J.A., 2002. N2 fixation by soybeans grown with different levels of mineral nitrogen, and the fertilizer replacement value for a following crop. Canadian Journal of Soil Science $82,139-145$

Karpenstein-Machan, M., Stuelpnagel, R., 2000. Biomass yield and nitrogen fixation of legumes monocropped and intercropped with rye and rotation effects on a subsequent maize crop. Plant \& Soil 218, 215-232.

Keeney, D.R., Nelson, D.W., 1982. Nitrogen-inorganic forms. In: Page, A.L., Miller, R.H., Keeney, D.R. (Eds.), Methods of Soil Analysis, second ed., Soil Science Society of America. Madison, WI, pp. 643-698.

Knudsen, D., Peterson, G.A., Pratt, P.F., 1982. In: Page, A.L., Miller, R.H., Keeney, D.R. (Eds.), Lithium, Sodium and Potassium. Methods of Soil Analysis, vol. 2, pp. 225-246.

Kosslak, R.M., Bookland, R., Barkei, J., Paaren, E.H., Appelbaum, E.R., 1987. Induction of Bradyrhizobium japonicum common nod genes by isoflavones isolated from Glycine max. Proceedings of the National Academy of Sciences 84, 7428-7432.

Kruskal, W.H., Wallis, W.A., 1952. Use of ranks in one-criterion variance analysis. Journal of the American Statistics Association 47, 583-621. 
Landini, S., Graham, M.Y., Graham, T.L., 2003. Lactofen induces isoflavone accumulation and glyceollin elicitation competency in soybean. Phytochemistry $62,865-874$.

Larose, G., Chênevert, R., Moutoglis, P., Gagné, S., Piché, Y., Vierheilig, H., 2002. Flavonoid levels in roots of Medicago sativa are modulated by the developmental stage of the symbiosis and the root colonizing arbuscular mycorrhizal fungus. Journal of Plant Physiology 159, 1329-1339.

McGonigle, T.P., Miller, M.H., 1861. Mycorrhizae, phosphorus absorption, and yield in response to tillage. Soil Science Society of America Journal 60, 1856-1861.

McGonigle, T.P., Miller, M.H., Evans, D.G., Fairchild, G.L., Swan, J.A., 1990. A new method which gives an objective measure of colonization of roots by vesicular-arbuscular mycorrhizal fungi. New Phytologist 115, 495-501.

Morandi, D., Branzanti, B., Gianinazzi-Pearson, V., 1992. Effect of some plant flavonoids on in vitro behaviour of an arbuscular mycorrhizal fungus. Agronomie 12, 811-816.

Morris, P.F., Savard, M.E., Ward, E.W.B., 1991. Identification and accumulation of isoflavonoids and isoflavone glucosides in soybean leaves and hypocotyls in resistance responses to Phytophthora megasperma f.sp. glycinea. Physiology \& Mololecular Plant Pathology 39, 229-244.

Mulyaney, B.L., 1993. Mass spectrometry. In: Knowles, R., Blackburn, T.H. (Eds.)., Nitrogen Isotope Techniques. Academic Press, San Diego, CA, pp.11-57.

Olsen, S.R., Summers, L.E., 1982. Phosphorus. In: Page, A.L., Miller, R.H., Keeney, D.R. (Eds.), Methods of Soil Analysis, second ed., Soil Science Society of America. Madison, WI, pp. 403-430.

Pueppke, S.G., Bolanos-Vasques, M.C., Werner, D., Bec-Ferte, M-P., Prome, J.C., Krishnan, H.B., 1998. Release of flavonoids by soybean cultivars McCall and Peking and their perception as signals by nitrogen-fixing symbiont Sinorrhizobium fredii. Plant Physiology 117, 599-608.
Richards, J.E., 1993. Chemical characterization of plant tissue. In: Carter, M.R. (Ed.), Soil Sampling Methods of Analysis Canadian Society of Soil Science. Lewis Publishers, Danvers, MA, pp. 115-139.

Schmidt, P.E., Broughton, W.J., Werner, D., 1994. Nod factors of Bradyrhizobium japonicum and Rhizobium sp, NG234 induce flavonoid accumulation in soybean root exudates. Molecular Plant-Microbe Interactions 7, 384-390.

Shapiro, S.S., Wilk, M.B., Chen, H.J., 1968. A comparative study of various tests of normality. Journal of the American Statistics Association 63, 1343-1372.

Thomas, R.L., Sheard, R.W., Moyer, J.R., 1967. Comparison of conventional and automated procedures for $\mathrm{N} \mathrm{P}$ and $\mathrm{K}$ analysis of plant material using a single digestion. Agronomy Journal 59, 240-243.

Thompson, J.P., 1990. Soil sterilization methods to show VA-mycorrhizae aid $\mathrm{P}$ and $\mathrm{Zn}$ nutrition of wheat in vertisols. Soil Biology \& Biochemistry 22, 229-240.

Tukey, J.W., 1949. Comparing individual means in the analysis of variance. Biometrics 5, 99-114.

Vejsadová, H., Siblíková, D., Gryndler, M., Simon, T., Miksik, I., 1993. Influence of inoculation with Bradyrhizobium japonicum and Glomus claroideum on seed yield of soybean under greenhouse and field conditions. Journal of Plant Nutrition 16, 619-629.

Volpin, H., Elkind, Y., Okon, Y., Kapulnik, Y., 1994. A vesicular arbuscular mycorrhizal fungus (Glomus intraradix) induces a defence response in alfalfa roots. Plant Physiology 104, 683-689.

Xie, Z.-P., Staehelin, C., Vierheilig, H., Wiemken, A., Jabbouri, S., Broughton, W.J., Vögeli-Lange, R., Boller, T., 1995. Rhizobial nodulation factors stimulate mycorrhizal colonization of nodulating and nonnodulating soybeans. Plant Physiology 108, 1519-1525.

Yadav, D.S., Antil, R.S., Singh, M., Kumar, V., 1986. Effect of P and Zn on number of nodules, nodule weight, leghaemoglobin content, $\mathrm{N}$ utilization and fixation in cowpea (Vigna unguiculata L. Walp.). Agrochimica 30, 252-260. 